Article

\title{
Case Study and Feasibility Analysis of Multi-Objective Life Cycle Energy System Optimization in a Nordic Campus Building
}

\author{
Vilppu Eloranta ${ }^{1, *}$, Aki Grönman ${ }^{2}\left(\mathbb{D}\right.$ and Aleksandra Woszczek ${ }^{2}$ \\ 1 Faculty of Technology, LAB University of Applied Sciences, Mukkulankatu 19, 15210 Lahti, Finland \\ 2 School of Energy Systems, LUT University, Yliopistonkatu 34, 53850 Lappeenranta, Finland; \\ aki.gronman@lut.fi (A.G.); aleksandra.woszczek@lut.fi (A.W.) \\ * Correspondence: vilppu.eloranta@lab.fi
}

check for

updates

Citation: Eloranta, V.; Grönman, A.; Woszczek, A. Case Study and

Feasibility Analysis of

Multi-Objective Life Cycle Energy

System Optimization in a Nordic

Campus Building. Energies 2021, 14,

7742. https://doi.org/10.3390/

en14227742

Academic Editors: Cynthia Hou and Gianpiero Colangelo

Received: 5 October 2021

Accepted: 15 November 2021

Published: 18 November 2021

Publisher's Note: MDPI stays neutral with regard to jurisdictional claims in published maps and institutional affiliations.

Copyright: (c) 2021 by the authors. Licensee MDPI, Basel, Switzerland. This article is an open access article distributed under the terms and conditions of the Creative Commons Attribution (CC BY) license (https:/ / creativecommons.org/licenses/by/ $4.0 /)$.

\begin{abstract}
Due to the high energy consumption of buildings, there is a demand for both economically and environmentally effective designs for building energy system retrofits. While multi-objective optimization can be used to solve complicated problems, its use is not yet widespread in the industry. This study first aims to develop an efficient and applicable multi-objective building energy system optimization method, used to dimension energy production and storage retrofit components in a case campus building in Lahti, Finland. Energy consumption data of the building are obtained with a dynamic energy model. The optimization model includes economic and environmental objectives, and the approach is found to function satisfactorily. Second, this study aims to assess the feasibility and issues of multi-objective single-building energy system optimization via the analysis of the case optimization results. The results suggest that economically beneficial local energy production and storage retrofits could not always lead to life cycle $\mathrm{CO}_{2}$-eq emission reductions. The recognized causes are high life cycle emissions from the retrofit components and low Nordic grid energy emissions. The performed sensitivity and feasibility analyses show that correctness and methodological comparability of the used emission factors and future assumptions are crucial for reliable optimization results.
\end{abstract}

Keywords: building energy system optimization; renewable energy retrofit; life cycle emission

\section{Introduction}

Buildings and their construction consume over one-third of the total global energy consumption and cause almost $40 \%$ of the global carbon dioxide $\left(\mathrm{CO}_{2}\right)$ emissions [1], and $36 \%$ of the $\mathrm{CO}_{2}$ emissions in the European Union (EU). The EU Energy Performance of Buildings Directive (EPBD) already requires new buildings to be nearly zero-energy buildings (NZEB); however, the EU building stock is also rather old and slowly renovated. Therefore, retrofits and modernizations to existing properties offer large energy performance and sustainability potential [2]. Thus, there is a need for reliable methods to identify the best-performing retrofit and modernization targets.

In a typical Finnish design, on-site renewable energy production, especially photovoltaic (PV) generation, is dimensioned to maximize self-utilization of the produced energy in the building, and therefore, to minimize the excess production, usually exported to the grid [3]. To increase peak renewable energy production, exported energy needs to be increased, demand flexibility needs to be implemented, or storage technologies need to be utilized. If energy storage is added to the system, dimensioning becomes complicated because of component interdependency. The system state is defined not only by current energy flows but also by past energy flows that manifest in storage state-of-charge. Therefore, energy systems containing storage components cannot be easily dimensioned with traditional methods, and the design must often be assisted with simulation.

Dynamic building energy simulation software, such as IDA ICE [4], EnergyPlus [5], and TRNSYS [6], couple the indoor zone conditions and energy system state at each 
timestep. Dynamic models can include the entire building with its HVAC systems and onsite energy sources, including solar and geothermal. The software can be used for various purposes, such as dimensioning the energy system components, assessing indoor climate conditions, or verifying certifications. However, once the problem becomes truly dynamic and interdependent with storage systems, fully dynamic approaches are computationally intensive. One approach is to draft multiple scenarios with different component sizes, and run the full dynamic simulation for each case [7]. The optimal case may be chosen based on the results. However, this brute force approach requires a lot of manual work and computational resources and might, therefore, not be feasible in some applications.

This problem can be solved through separating the optimization from the dynamic model. Several multi-stage energy system optimization approaches for buildings have been recently studied, utilizing dynamic energy modeling tools such as EnergyPlus [8-11] or IDA ICE [12] to obtain the demand data. Optimization is then performed with separate tools, such as MATLAB, either with or without linking it to the dynamic simulation software. Studied and tested algorithms include linear programming (LP) [13-15], mixed-integer linear programming (MILP) [8,16,17], genetic algorithm (GA) [9,10,12,18], and particle swarm optimization (PSO) [11,19].

Energy system optimization approaches have not yet become widespread in practical system design processes. Challenges of utilizing energy optimization in these workflows have been analyzed via specialist interviews [20] and literature reviews [21]. The interview study [20] found various issues, such as variation of methods, high required expertise, validity concerns, required computation and time resources, lacking or poor-quality input data, and lack of production-ready tools. Nguyen et al. [21] state problems such as missing interfaces between simulation and optimization software, difficulty of adequate trade-offs between accuracy and simplicity, and lack of policies enforcing the use of optimization. Moreover, integration of life cycle emission considerations to building design processes is problematic due to inconsistent values and methods. Identified issues include noncomparable reporting standards, operational vs. embodied emissions, and region-specific and inadequate calculation tools [22].

Due to the old EU building stock and the need to improve its energy performance, energy retrofits and their optimization has been studied broadly. Ibañez Iralde et al. [23] reviewed the current energy retrofit measures and funding for residential buildings in Spain, and specified retrofit possibilities. Galatioto et al. [24] reviewed the feasibilities of energy retrofits in historical Italian buildings, considering insulation, energy storage, and intelligent control actions, among other possibilities. Gagliano et al. [25] compared the configuration scenarios of PV panels, battery capacities and energy consumption profiles in residential applications to minimize energy exchange with the grids. He et al. [26] presented a comprehensive retrofit analysis considering wall insulation, piping system, occupancy sensors, and other means. Nocera et al. [27] performed a retrofit analysis for a hotel in Italy, studying broad actions to achieve nearly zero-energy building (nZEB) status. Pirmohamadi et al. [28] demonstrated an optimization approach for an office solar thermal system in Iran to optimize energy consumption, and economic and environmental costs. These studies, however, take place outside the Nordic conditions characterized by cold climate and relatively low electricity and heat energy prices. Moreover, the introduced studies do not consider life cycle emissions from the retrofit equipment manufacturing.

From these premises, this study first aims to develop a computationally efficient and applicable multi-objective building energy system optimization method for energy system component dimensioning, utilizing balanced economic and environmental optimization objectives. The approach is based on linear optimization that can be applied in early design phases for either new construction or retrofit and requires either simulated or measured energy demand data of the building as an input. It extends previous research by developing a modular and user-friendly template, utilizing built-in components from the open-source energy system modeling framework Calliope [29]. The approach is used to dimension energy system component retrofits for a campus building in Lahti, Finland, 
and environmental life cycle optimization is enabled by obtaining component life cycle emission data from literature. Second, this study aims to assess the feasibility of economicenvironmental multi-objective single-building energy system optimization by analyzing result reliability and comparability. The process is enabled by sensitivity, feasibility, and qualitative analyses of the case optimization results, from which potential actions and best practices are derived and discussed.

The article is organized as follows: first, the applied modeling approaches are presented, including the model validation and used parameters. Second, the optimization results are presented along with sensitivity analyses and further insights. Last, the results are discussed along with future research needs and conclusions.

\section{Methodology}

The case building in Lahti, Finland is a repurposed furniture factory, currently accommodating production, office, storage, and campus spaces. Floor plans of the building are available in Appendix A. The building was originally built in the 1950s and partly modernized in the late 2010s, when $111 \mathrm{~kW}$ photovoltaic (PV) solar panels and a $1 \mathrm{MW}$ ground source heat pump (GSHP) system with ground boreholes were installed. The building is connected to the local district heat (DH) network.

As the building consists of several parts and is partially renovated, it contains structural parts from different eras, differing in heat conductivity. Original windows have double glazing, i.e., inner and outer frames with single panes, whereas modernized windows have triple glazing, i.e., inner frames with two pane insulating glass elements and outer frames with single panes. Large glazing areas have solar control glass.

Due to the northern location of Finland, the achievable PV production profile is distinct with high insolation in the long summer days, and low in the short winter days [30]. Hence, utilizing excess PV electricity production in the summer to drive heat pumps and storing the generated heat seasonally could be one solution to balance this characteristic. Combining PV production and heat pump with battery [31] or thermal storage [32] have been studied; however, the integration of these systems in Nordic conditions still needs further research. The feasibility of this concept is investigated in the results.

As this study focuses exclusively on the building energy system, other means of energy performance improvement, such as renovation, insulation improvement, occupant coaching, or schedule optimization, are not considered.

\subsection{Dynamic Building Energy Model and Validation}

Energy demand data for the building were obtained with dynamic building simulation software IDA Indoor Climate and Energy (IDA ICE) [4]. The building geometry was derived from floor plans and by site inspection. Thermodynamic properties, such as thermal conductivities, were sourced from structural design documentation and by inspection, and they are presented in Table 1 . The model floor area is $79,184 \mathrm{~m}^{2}$ and the volume $374,643 \mathrm{~m}^{3}$.

Table 1. Areas and heat conductivities of the building structures in the dynamic energy model. Heat conductivity is presented as the average value with the range of various structures in parentheses.

\begin{tabular}{ccc}
\hline Structure & Area $\left[\mathbf{m}^{\mathbf{2}}\right]$ & Heat Conductivity $\left[\mathbf{W} /\left(\mathbf{m}^{\mathbf{2}} \mathbf{K}\right)\right]$ \\
\hline External wall & 16,250 & $0.42(0.17-0.66)$ \\
Roof & 25,387 & $0.31(0.09-0.40)$ \\
Slab, external floor & 25,524 & $0.56(0.11-0.59)$ \\
Glazing to north & 2125 & $2.02(1.00-2.90)$ \\
Glazing to east & 900 & $1.38(1.00-2.90)$ \\
Glazing to south & 1743 & $2.21(1.00-2.90)$ \\
Glazing to west & 2459 & $1.17(1.00-2.90)$ \\
\hline
\end{tabular}


The default energy plant model of IDA ICE was used, containing simple heating and cooling heat exchangers with unlimited capacities. Heating distribution fluid temperature was set to adjust linearly based on the ambient temperature, from $70{ }^{\circ} \mathrm{C}$ at $-30{ }^{\circ} \mathrm{C}$ ambient to $20^{\circ} \mathrm{C}$ at $+20^{\circ} \mathrm{C}$ ambient, and the zones were heated with water radiators with $21^{\circ} \mathrm{C}$ setpoints. Indoor cooling was performed mainly via chilled supply air with $24^{\circ} \mathrm{C}$ zone setpoints. The standard IDA ICE air handling unit model was used, implementing a heat recovery exchanger with 50\% efficiency and supply air heating and cooling. Constant supply air temperature was set at $17^{\circ} \mathrm{C}$ and fan operation schedule to 6:00-19:00 on workdays. Office and learning spaces were configured for temperature-controlled variable air flows from $2 \mathrm{~L} /\left(\mathrm{s} \mathrm{m}^{2}\right)$ to $4 \mathrm{~L} /\left(\mathrm{s} \mathrm{m}^{2}\right)$, and standard spaces with constant air flows of $2 \mathrm{~L} /\left(\mathrm{s} \mathrm{m}^{2}\right)$. Occupancy, internal load, and indoor lighting schedule was set to 7:00-19:00 on workdays. ASHRAE IWEC2 weather data [33] for Lahti, Finland, and the default IDA ICE urban wind profile were used. The model construction, visible in Figure 1, was simplified by combining zones and windows to ensure practical simulation times with satisfactory resolution. The simplified model contains 111 window and 70 opening or door elements.

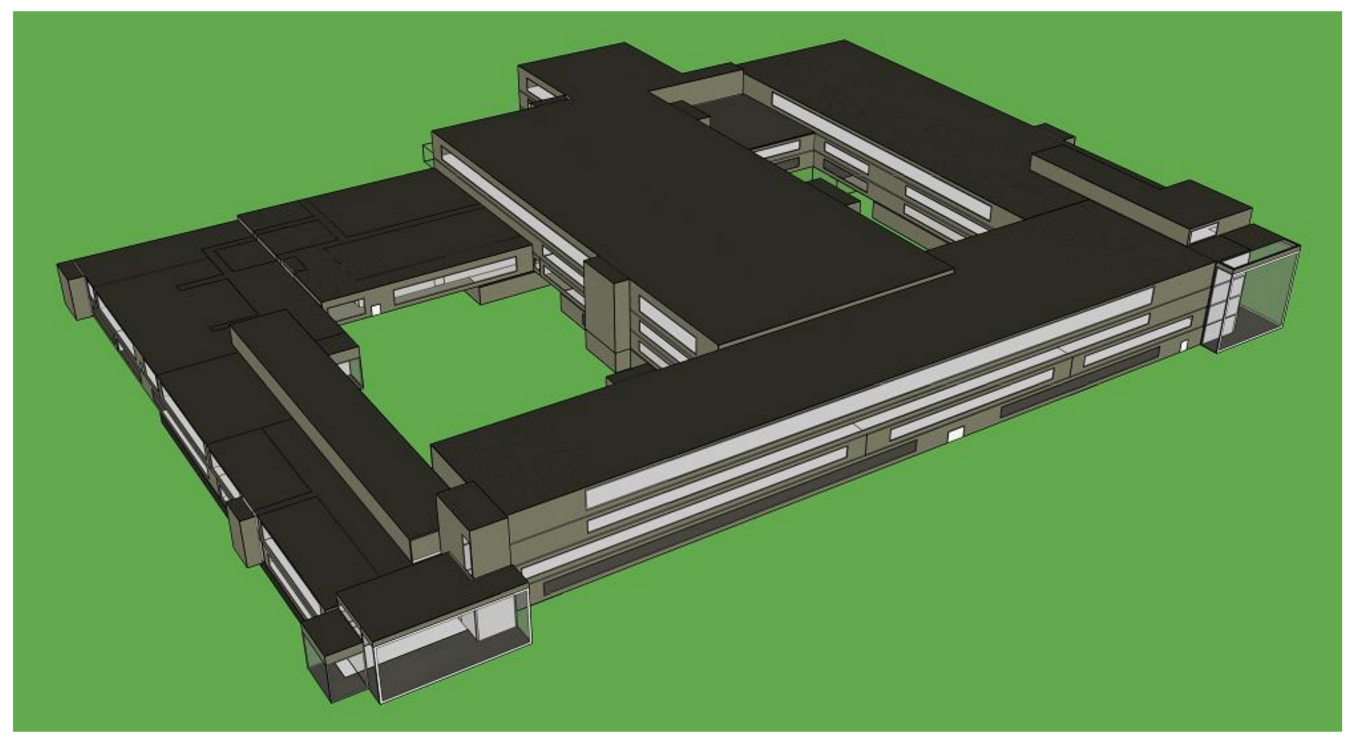

Figure 1. Dynamic campus building energy model constructed in IDA ICE. Walls, roofs, doors, and windows are visible in the three-dimensional representation. The long facade in the forefront is facing west.

The model was validated by comparing monthly simulated space heating and cooling energy consumptions with measured data from the building, which includes GSHP heating and cooling and imported district heat energies for the year 2020. In Finland, annual variations of space heating energy consumption data are standardized according to [34]:

$$
Q_{\text {std }}=\frac{S_{\mathrm{N}}}{S_{\mathrm{R}}} Q_{\mathrm{R}}+Q_{\mathrm{DHW}}
$$

where $Q_{\text {std }}$ is the standardized space heating energy consumption, $S_{N}$ the average reference value for the location, $S_{R}$ the realized reference number for the location, $Q_{R}$ the realized energy consumption for the current year, and $Q_{\mathrm{DHW}}$ the domestic hot water energy consumption to be excluded from the standardization. Since the available measured data are consolidated with no possibility to separate the energy used for DHW heating, the correction was performed inversely on the simulated data to convert them to the year 2020 . Therefore, $Q_{R}$ is solved by Equation (1), resulting in:

$$
Q_{\mathrm{R}}=\frac{S_{\mathrm{R}}}{S_{\mathrm{N}}}\left(Q_{\text {std }}-Q_{\mathrm{DHW}}\right),
$$


where $Q_{\text {std }}$ is now the energy consumption input from the simulated data.

The relative reference values for Lahti, Finland for the whole year of 2020 are $S_{R}=3438$ and $S_{N}=4392$ [35], indicating a warmer year than usual. In the model validation, the monthly heating degree days values for the year 2020 [35] were used. Monthly comparison of measured energy consumption data and corrected simulated values for model validity assessment is presented in Table 2.

Table 2. Corrected simulated monthly energy consumption data from IDA ICE is compared to the measured data from 2020. The simulated values are corrected to represent the year 2020 through the heating degree days correction. The data are used for the validation of the energy consumption model.

\begin{tabular}{cccc}
\hline Month & Measured [MWh] & Simulated (IDA ICE) [MWh] & Difference [MWh] \\
\hline January & 1002 & 899 & -103 \\
February & 939 & 835 & -104 \\
March & 927 & 776 & -150 \\
April & 603 & 671 & 69 \\
May & 410 & 409 & -1 \\
June & 246 & 133 & -113 \\
July & 249 & 247 & -2 \\
August & 223 & 203 & -21 \\
September & 274 & 194 & -80 \\
October & 465 & 480 & 15 \\
November & 672 & 735 & 64 \\
December & 750 & 890 & 140 \\
Whole year & 6760 & 6474 & -285 \\
\hline
\end{tabular}

Although some monthly and seasonal variance is visible in the data in Table 2, the annual difference of $-4.2 \%$ and the similar trend shapes between measured and simulated data were considered to validate the energy consumption model for use in this study.

\subsection{Modular Energy System Model}

The building energy system model was constructed with an open-source linear programming energy system modeling framework Calliope [29]. The framework enables multi-objective optimization with a linear programming solver of choice; in this case, COIN-OR Branch-and-Cut (CBC) solver was used. The problem was defined as linear programming (LP) instead of mixed integer linear programming (MILP), since values such as storage capacity can reduce to zero to represent an absent equipment, and no binary investment costs are included.

The model is based on energy balances of each modeled component, fulfilling the energy balance at each timestep for each separate location, technology, and energy carrier. In this single-building case, there is only one location, and the balance is written as follows [36]:

$$
E_{\text {prod }}(\text { tech }:: \text { carrier })+E_{\text {con }}(\text { tech }:: \text { carrier })+E_{\text {export }}(\text { tech }:: \text { carrier })=0
$$

where for a specific technology in an energy carrier (tech :: carrier), $E_{\text {prod }}$ is the energy produced in or brought to the node, $E_{\text {con }}$ is consumed, and $E_{\text {export }}$ is exported.

In this case, three main energy carriers were included in the model: electricity, heating, and cooling. The heat carrier is divided into high- and low-temperature subcarriers: hightemperature heat is always imported from district heat, while low-temperature heat can be sourced from GSHP or storage. At least $50 \%$ of DHW heating power is always sourced from the high-temperature subcarrier. The overall structure of the model components and carriers is presented in Figure 2. 


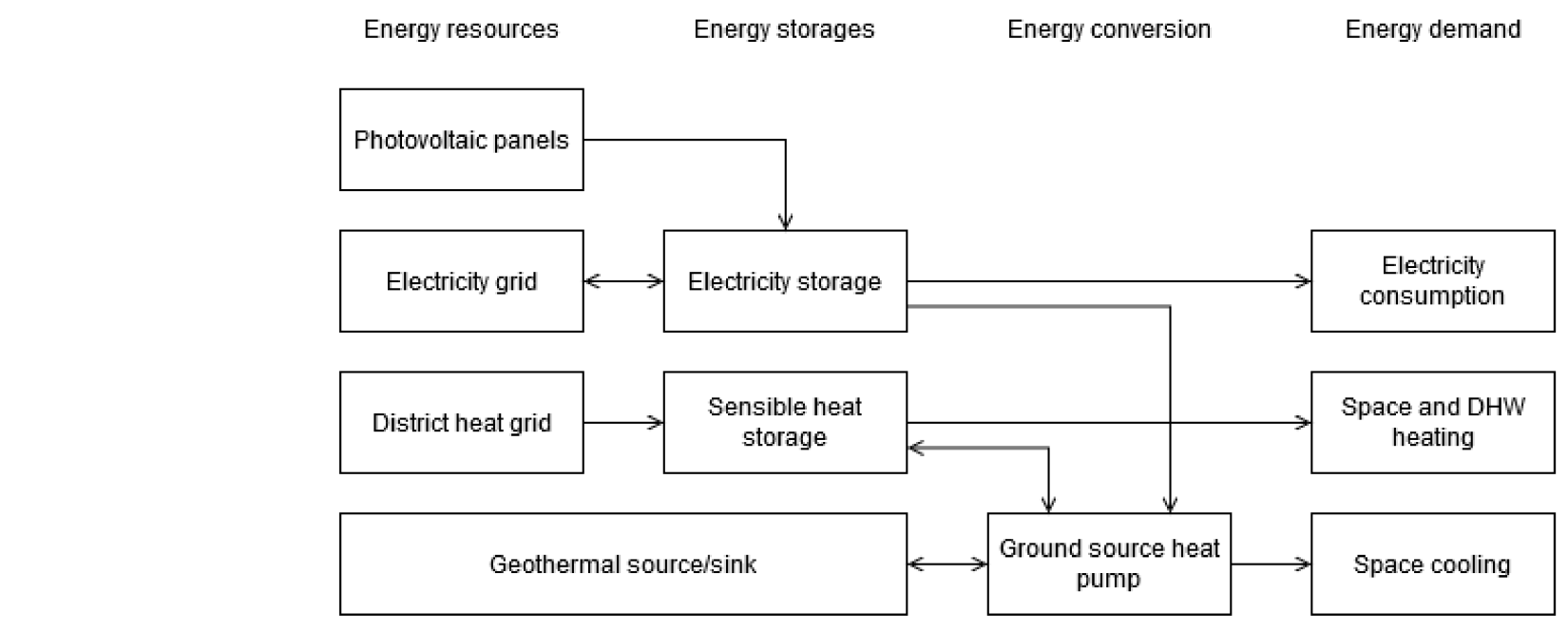

Figure 2. Diagram of the energy system optimization model for this specific case. The main component enabling flexibility is the ground source heat pump, which links separate energy carriers through its energy conversion ability. In this model, energy demands are pre-defined from the dynamic building model data.

The model configuration optimizes three parameters: PV panel peak power, heat storage capacities, and electricity storage capacities. The system's lifetime is 25 years and the real interest rate is $5 \%$. Emissions are considered with no depreciation rate. The following subsubsections describe the individual components modeled in the energy system model, as well as their mathematical formulations.

\subsubsection{GSHP Model}

The GSHP is a central component in the model, as it enables power-to-heat conversion when excess PV production is available. It was simplified as an energy conversion component with constant conversion ratios, following Equation (4) [36] in each timestep. Using the constant coefficient of performance (COP) for heating and energy efficiency ratio (EER) for cooling is reasonable, as the heat pump evaporator and condenser temperatures stay quite constant in operation.

$\sum_{\text {tech::carrier, out }} \frac{E_{\text {prod }}(\text { tech }:: \text { carrier })}{R(\text { tech }:: \text { carrier }, \text { out })}=-\sum_{\text {tech::carrier, in }} E_{\text {con }}($ tech $::$ carrier $) \times R($ tech $::$ carrier, in $) \times \eta($ tech $)$

where $R$ is the set carrier conversion ratio. Here, the ratios correspond to COP and EER and include the conversion efficiency $\eta(t e c h)$. Thus, this specific GSHP is modeled as:

$$
\frac{E_{\text {prod }}(\text { GSHP }:: \text { heat })}{\text { COP }}+\frac{E_{\text {prod }}(\text { GSHP }:: \text { cooling })}{\text { EER }}=-E_{\text {con }}(\text { GSHP :: electricity }) \times 1
$$

The measured GSHP production data from the site data showed a combined productionweighted average COP/EER 3.8, calibrated IDA ICE GSHP model COP 3.3 and EER 4.8, and system datasheets COP 3.3 and EER 4.3 at design operating points. The datasheet values were selected and resulted in approximately $50{ }^{\circ} \mathrm{C}$ condensing temperature both in the IDA ICE model and datasheets.

In GSHP systems, too intense heat removal can lead to freezing of borehole water and the surrounding soil [37], and therefore, the borehole heat extraction power must be limited. Real systems are often controlled with pre-set operation modes for different ambient temperatures. In the location, geothermal potential is approximately $7 \mathrm{~kW}$ per one $300 \mathrm{~m}$ borehole [38], which scales to $368 \mathrm{~kW}$ for the entire borehole field. Maximum GSHP compressor power of $300 \mathrm{~kW}$ fulfilled the condition on annual level. 


\subsubsection{Solar Generation and Energy Storage Technologies}

The modeled PV capacity was constrained to a range from the present $111 \mathrm{~kW}$ to the maximum that was estimated to fit the building roof, i.e., $555 \mathrm{~kW}$. Widely commercially available mono- or polycrystalline silicon panels were chosen, for which price and carbon dioxide-equivalent $\left(\mathrm{CO}_{2}\right.$-eq) life cycle emission data are widely available. The used parameters for the PV production component are listed in Table 3.

Table 3. Boundaries and specific parameter for photovoltaic systems.

\begin{tabular}{cc}
\hline Parameter & Value \\
\hline Maximum total peak power $\left[\mathrm{kW}_{\text {peak }}\right]$ & 555 \\
Specific cost $\left[€ / \mathrm{kW}_{\text {peak }}\right]$ & $1000[39]$ \\
Specific emission $\left[\mathrm{kg} \mathrm{CO} \mathrm{CO}_{2}\right.$-eq $\left./ \mathrm{kW}_{\text {peak }}\right]$ & $1200[40,41]$ \\
\hline
\end{tabular}

Thermal storage was modeled as a water tank sensible heat storage, as the other alternative, phase change material (PCM) latent heat storage, is not yet technologically mature enough. Furthermore, the available cost and life cycle emission data of PCM storages is scarce and uncertain. Electrical storage was modeled as a lithium-ion battery due to its wide commercial availability and data availability. The simulated storage energy states are defined according to Equation (6) [36], in which the current charge state is defined via the previous timestep state:

$$
E_{\text {storage }}(\text { tech, timestep })=E_{\text {storage }}\left(\text { tech }_{\text {timestep }} \text { - } 1\right)-E_{\text {con }} \eta(\text { tech })-\frac{E_{\text {prod }}}{\eta(\text { tech })}
$$

where $E_{\text {storage }}$ is the charge of the observed storage and $\eta($ tech $)$ is the technological charge and discharge efficiency including all losses. Relevant constraints and values for the thermal and electrical storage systems are listed in Table 4.

Table 4. Cost, emission, and performance parameters for on-site storage components.

\begin{tabular}{ccc}
\hline Parameter & Thermal Storage & Electricity Storage \\
\hline Storage capacity limit $[\mathrm{MWh}]$ & 10 & 10 \\
Power-to-energy ratio $[\mathrm{kW} / \mathrm{kWh}]$ & 0.1 & 1 \\
Round trip efficiency [\%] & $81[42]$ & $90[43]$ \\
Specific cost $[€ / \mathrm{kWh}]$ & $20[42]$ & $300[43]$ \\
Specific emission $[\mathrm{kg} \mathrm{CO}-\mathrm{eq} / \mathrm{kWh}]$ & $0.011[44]$ & $150[45,46]$ \\
\hline
\end{tabular}

\subsubsection{Cost and Emission Factors of Energy Grid Connections}

Emission factors for imported energies can be defined by accounted, average, marginal. or other values. Although electricity and district heat can be bought as accounted carbonfree products from the utilities, the actual delivered energy can be from mixed sources. In this model, average values for the connected grids were used. The current national electricity emission factor is approximately $72 \mathrm{~g} \mathrm{CO}_{2} / \mathrm{kWh}$ [47], and the local district heat emission factor is $57 \mathrm{~g} \mathrm{CO}_{2} / \mathrm{kWh}$ [48]. Emission factors for electricity and district heat are assumed to decrease linearly and reach zero after 25 years. Energy import costs are the total empirical values for the case, including energy, transmission, and tax components. Exported electricity compensation includes only the energy component, and thus, it is lower than the total cost of imported energy. The values are consolidated in Table 5. 
Table 5. Cost and emission parameters for energy grid connections.

\begin{tabular}{ccc}
\hline Parameter & Electricity & District Heat \\
\hline Specific energy cost $[€ / \mathrm{kWh}]$ & $0.10[49,50]$ & $0.05[51]$ \\
Exported energy compensation $[€ / \mathrm{kWh}]$ & $0.03[52]$ & - \\
Current $\mathrm{CO}_{2}$ emission $\left[\mathrm{g} \mathrm{CO}_{2} / \mathrm{kWh}\right]$ & $72[47]$ & $57[48]$ \\
Projection, after 25 years $\left[\mathrm{g} \mathrm{CO}_{2} / \mathrm{kWh}\right]$ & 0 & 0 \\
Averaged over lifetime $\left[\mathrm{g} \mathrm{CO}_{2} / \mathrm{kWh}\right]$ & 36 & 28.5 \\
\hline
\end{tabular}

\subsubsection{Life Cycle Cost and Emission Calculation}

Life cycle costs and emissions were calculated with Calliope, following Equation (7) [36]. Emissions from maintenance operations were not considered separately, as they are not a significant part of the total life cycle emissions in this case. However, they can be included in other models or applications, if necessary.

$$
C(\text { cost }, \text { tech })=C_{\text {inv }}(\text { cost, tech })+\sum_{\text {timestep } \in \text { timesteps }} C_{\mathrm{var}}(\text { cost, tech, timestep })
$$

where $C$ (cost, tech) represents the cost for a single cost type (cost, such as monetary or $\mathrm{CO}_{2}$-eq) and for a single technology (tech). $C_{\mathrm{inv}}$ is the present value of investment and $C_{\mathrm{var}}$ is the present value of variable costs for each considered timestep. The total system cost or emission for the entire lifetime is calculated by summing all individual technology cost values calculated with Equation (7).

\section{Results}

The photovoltaic panel, thermal storage, and electrical storage retrofits were optimally dimensioned for the case building for three objective scenarios, which minimize the objective functions for the system lifetime of 25 years:

- Economic: cost $100 \%$.

- Balanced: cost 50\%, emissions 50\%.

- Environmental: emissions $100 \%$.

The optimization results are presented in Table 6. Compared to the reference scenario, in all modified scenarios, the GSHP can be at least $5 \%$ better utilized in heating due to more available renewable electricity or the added thermal storage component. Electricity storage (lithium-ion battery) is not deployed on any objective due to high life cycle costs and emissions.

As the data in Table 6 shows, in the economic scenario, maximum possible PV generation capacity and some thermal storage is installed. This setup provides a total energy import reduction of over $5 \%$ annually, but considering life cycle emissions from the equipment, it causes 6.5 tons more annual $\mathrm{CO}_{2}$-eq emissions compared to the reference scenario. This converts to a $2.6 \%$ life cycle increase. The large increase of PV production capacity leads to more electricity exports than in the reference scenario, which is especially noticeable on the self-used PV electricity ratio of 90\% (approximately nine percentage points lower than in the reference results). The rather small compensation of exported electricity $0.03 € / \mathrm{kWh}$ keeps the arrangement profitable.

The balanced scenario increases annual costs slightly while reducing emissions roughly by $1 \%$, enabled by thermal energy storage at $2.5 \mathrm{MWh}$ capacity. It is notable that high $\mathrm{CO}_{2}$-eq emissions from PV panel production block additional installations even in this half-environmental objective. DH imports are replaced with electricity imports due to more extensive use of GSHP heating.

In the environmental scenario, the thermal storage capacity is increased to the cap of $10 \mathrm{MWh}$, with an annual cost increase of almost $10 \mathrm{k} €$. This option seems the least desirable for the building owner, even though the GSHP can be very well utilized. 
Table 6. Energy system optimization results and parameters for the three optimization objectives simulated in Calliope, compared to the reference case.

\begin{tabular}{|c|c|c|c|c|}
\hline & Reference & Economic & Balanced & Environmental \\
\hline Installed PV peak power [kW] & 111 & 555 & 111 & 111 \\
\hline Installed heat storage [kWh] & 0 & 1982 & 2619 & 10,000 \\
\hline Installed electricity storage [kWh] & 0 & 0 & 0 & 0 \\
\hline GSHP heat production [TWh/a] & 4.92 & 5.17 & 5.21 & 5.39 \\
\hline Production change to reference [\%] & & +5.0 & +5.8 & +9.5 \\
\hline PV exports [MWh/a] & 0.98 & 46.05 & 0.00 & 0.00 \\
\hline PV self-use ratio [\%] & 99.0 & 90.3 & 100.0 & 100.0 \\
\hline Electricity import [TWh/a] & 5.38 & 5.12 & 5.46 & 5.52 \\
\hline DH import [TWh/a] & 2.54 & 2.35 & 2.31 & 2.16 \\
\hline Total energy import [TWh/a] & 7.92 & 7.47 & 7.78 & 7.68 \\
\hline Import change to reference [\%] & & -5.7 & -1.8 & -3.0 \\
\hline Cost of energy imports $[\mathrm{k} € / \mathrm{a}]$ & 665.1 & 629.5 & 662.1 & 660.2 \\
\hline Cost of investments $[\mathrm{k} € / \mathrm{a}]$ & 0.0 & 33.1 & 3.7 & 14.2 \\
\hline Cost change to reference $[\%]$ & & -0.4 & +0.1 & +1.4 \\
\hline $\mathrm{CO}_{2}$ from energy imports $\left[\mathrm{t} \mathrm{CO}_{2} / \mathrm{a}\right]$ & 266.1 & 251.3 & 262.6 & 260.4 \\
\hline $\mathrm{CO}_{2}$-eq from equipment $\left[\mathrm{t} \mathrm{CO}_{2} / \mathrm{a}\right]$ & 0.0 & 21.3 & 0.0 & 0.0 \\
\hline $\mathrm{CO}_{2-}$ eq change to reference [\%] & & +2.6 & -1.2 & -1.9 \\
\hline
\end{tabular}

\subsection{Sensitivity from Imported Energy Prices and Emissions}

Result sensitivity was assessed by varying the uncertain inputs and assumptions of the energy system model: future imported energy price, grid emission factors and their projections. The assessment was performed on three scenarios, simulated for each optimization objective to enable evaluating effects from both monetary and emission factors:

A. All imported electricity and district heat is considered zero-emission for the whole simulation period. Procurement of carbon-neutral energies raise the specific costs of imported energy by $20 \%$ in the model. It is acknowledged that full life cycle emissions are neglected, and actual emissions could be compensated in accounting. B. Instead of carbon-neutral electricity and DH networks after 25 years, the specific emissions will only reduce linearly to $50 \%$ from current levels. In the model, the emission factors for imported energy are increased by $50 \%$.

C. This modification assumes that the cost of imported energy will increase linearly by $100 \%$ in 25 years, instead of staying at current inflation-corrected levels. In the model, the imported energy prices are increased by $50 \%$.

Figure 3 shows simulation results from the listed scenarios. Overall, the optimization results are very sensitive to assumptions about future energy prices and emissions. Lithiumion battery storage capacity remains at zero even in all the above scenarios.

The most apparent remark from Figure 3 is that in scenario A with environmental optimization objective, the optimized system obviously prefers importing all energy from the networks instead of installing any local production or storage equipment. This is clear, as installing new local equipment would produce life cycle emissions. However, it well represents the discrepancy of the available carbon emission values and the possibilities of creative $\mathrm{CO}_{2}$ accounting.

In scenarios $\mathrm{B}$ and $\mathrm{C}$, the modifications cause the largest effect in the balanced optimization objective (50\% monetary, 50\% emission), in which the installed PV power and heat storage capacities are greatly increased due to less desirable imports. However, even in the environmental objective in scenario $\mathrm{B}$, the $\mathrm{PV}$ power capacity is not increased due to its high specific emissions. 


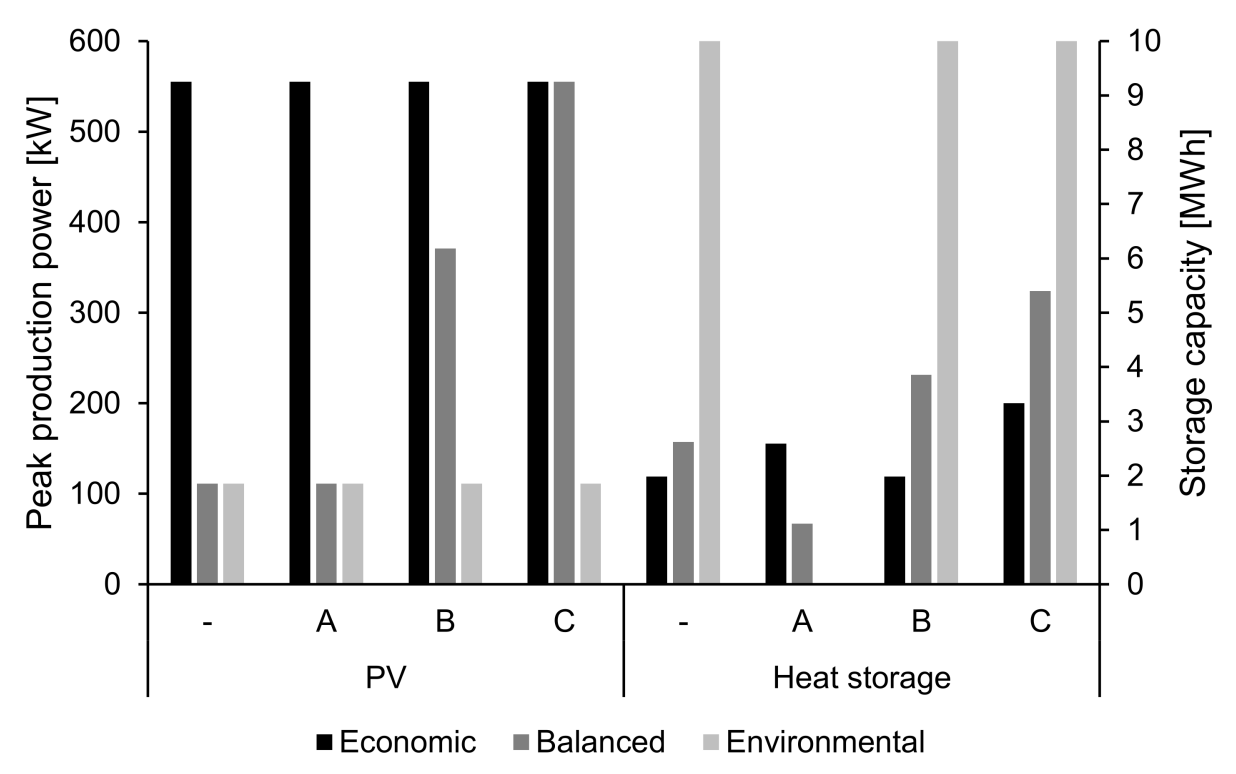

Figure 3. Sensitivity assessment results of optimization, in which the descriptions are as presented earlier. -: No modifications, original results. A: All imported energy is carbon neutral. B: Emission factors are increased 50\%. C: Cost factors are increased 50\%. Lithium-ion battery capacity remains zero in all scenarios, and thus, it is excluded from the graph.

\subsection{Feasibility of Component Life Cycle Emissions}

As no additional PV or electricity storage capacity were introduced in the environmental optimization results, a feasibility study for component life cycle emissions was conducted to determine the magnitude of necessary life cycle emission reductions to make the component installations environmentally feasible. At the same time, the specific component life cycle emission values sourced from literature are a major source of result uncertainty. Specific emission values for lithium-ion batteries vary greatly in the literature and depend on the manufacturing location. The current values range approximately $80-250 \mathrm{~kg} \mathrm{CO}_{2}$-eq/ $\mathrm{kWh}[45,46]$, and similarly, broad ranges are present in the PV and heat storage values. Therefore, sensitivity from the life cycle emission factors was assessed by varying the emission factors of all components, as in Table 7 . The optimization runs were performed for the environmental optimization objective, as the modifications cause no monetary impacts.

Table 7. Parameters for assessing the effects of varying component life cycle emission values.

\begin{tabular}{cccccc}
\hline Parameter & $\mathbf{- 7 5 \%}$ & $\mathbf{- 5 0 \%}$ & $\mathbf{- 2 5 \%}$ & Initial & $\mathbf{+ 5 0 \%}$ \\
\hline PV panel $\left[\mathrm{kg} \mathrm{CO}\right.$-eq $\left./ \mathrm{kW}_{\text {peak }}\right]$ & 300 & 600 & 900 & 1200 & 1800 \\
Water tank $\left[\mathrm{kg} \mathrm{CO}_{2}\right.$-eq/ $\left./ \mathrm{kWh}\right]$ & 0.00275 & 0.0055 & 0.00825 & 0.0110 & 0.0165 \\
Lithium-ion battery $\left[\mathrm{kg} \mathrm{CO}_{2}\right.$-eq $\left./ \mathrm{kWh}\right]$ & 37.5 & 75 & 112.5 & 150 & 225 \\
\hline
\end{tabular}

The simulations resulted in configurations presented in Table 8. In this specific case, a lithium-ion battery becomes environmentally feasible only in the $-75 \%$ scenario, with a specific life cycle emission of $37.5 \mathrm{~kg} \mathrm{CO}$-eq/ $\mathrm{kWh}$. According to the literature, this level is not currently achievable. PV installation becomes feasible in the $-50 \%$ scenario, resulting in maximum possible installation. The analysis also shows that correct component life cycle emission values are essential for reliable environmental optimization results. 
Table 8. Results of the component life cycle emission feasibility analysis.

\begin{tabular}{cccccc}
\hline Parameter & $\mathbf{- 7 5 \%}$ & $\mathbf{- 5 0 \%}$ & $\mathbf{- 2 5 \%}$ & Initial & $\mathbf{+ 5 0 \%}$ \\
\hline PV panel $\left[\mathrm{kW}_{\text {peak }}\right]$ & 555 & 555 & 111 & 111 & 111 \\
Water tank $[\mathrm{kWh}]$ & 10,000 & 10,000 & 10,000 & 10,000 & 10,000 \\
Lithium-ion battery $[\mathrm{kWh}]$ & 51 & 0 & 0 & 0 & 0 \\
\hline
\end{tabular}

\subsection{Power-to-Heat and Storage Interoperation}

As heat production with GSHP is cheaper and causes lower emissions than DH even with imported electricity due to the high COP, the model utilizes the GSHP to proactively store heat in the thermal storage for space and DHW heating. This power-to-heat operation mode is especially beneficial in the timesteps where PV production exceeds local electricity demand, which is often the case on weekends. For assessment, the economic scenario optimization result was used because of the maximum available PV generation. The optimized storage capacities are not suitable for seasonal storage, but sufficient for interday buffer. Figure 4 shows system operation for the first week (Monday-Friday) of July including the leading weekend (Saturday-Sunday), when excess PV production is available.

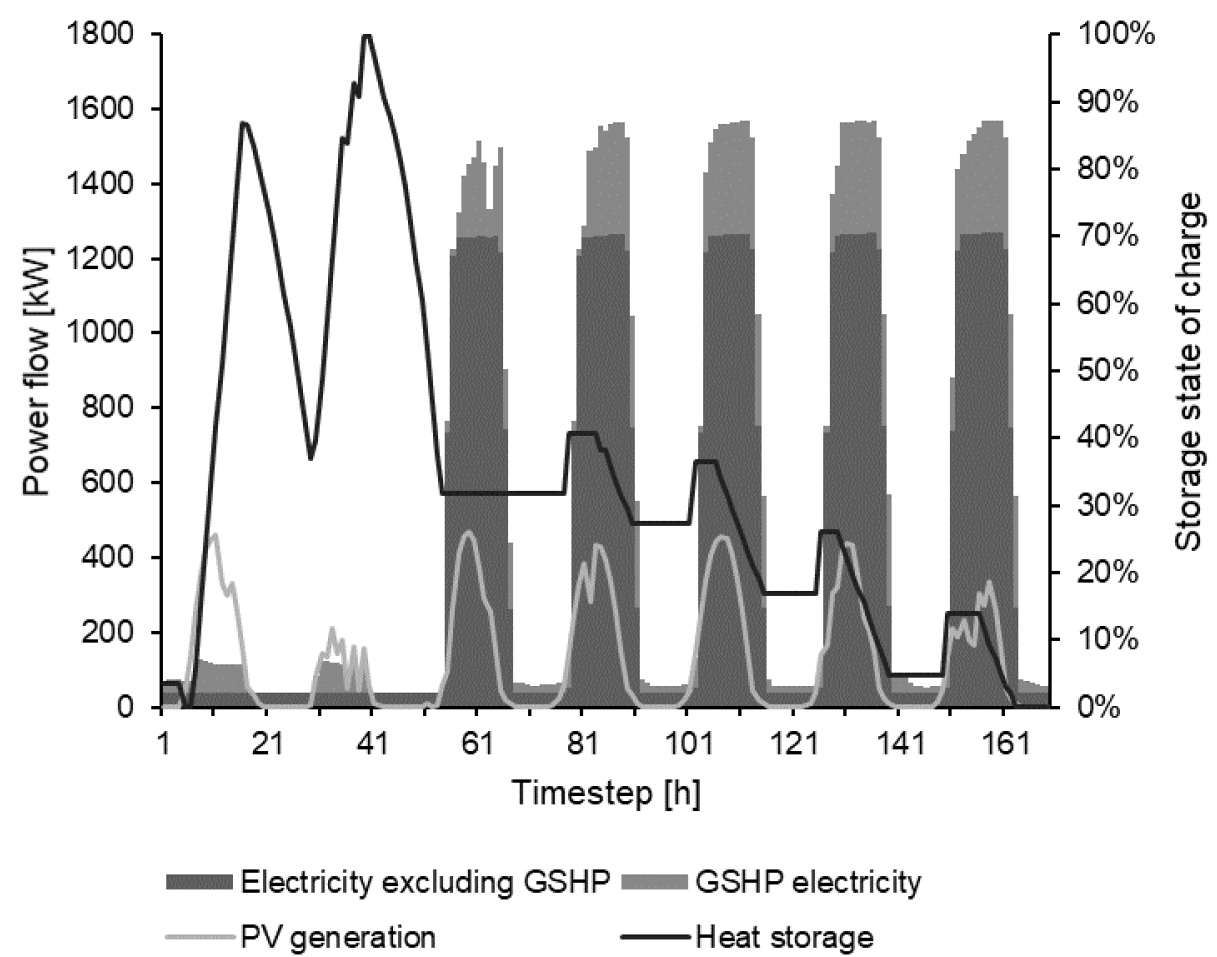

Figure 4. Demonstration of power-to-heat and storage interoperation from the simulated data. The graph shows one-hour timesteps for the first week (Monday-Friday) of July, including the leading weekend (Saturday-Sunday).

Figure 4 shows the thermal storage charging to 100\% state-of-charge (SOC) during the weekend using heat generated with GSHP, when the local photovoltaic generation exceeds the total electricity demand. The storage is then optimally discharged during the week by utilizing the heat mainly for DHW heating.

\section{Discussion and Conclusions}

In this study, a new building energy system optimization approach was developed. The approach was tested for a case campus building, for which energy consumption data were generated with a dynamic energy model. The consumption data were used to develop an energy system optimization model, which in this case was used to dimension 
photovoltaic (PV) generation and storage equipment. The optimization objectives were both monetary cost and carbon dioxide equivalent $\left(\mathrm{CO}_{2}\right.$-eq) emissions. The developed method was identified to function satisfactorily in the case study, and the optimization results served as the material for the feasibility analysis of multi-objective optimization.

The developed energy system optimization model sees input data from dynamic building simulation or measurements as "black box", taken as provided. The black box nature of the input data reduces the computational load and sensitivity in the optimization phase. For existing buildings, measured data could also be used. The approach prevents considering energy demand flexibility, and possible thermodynamic effects to the building structures are also neglected. Comprehensive modeling of these factors would require a more integrated optimization solution, potentially implemented directly in the dynamic building simulation software. Integrated optimization, however, requires considerably more computational resources, while the industry needs an easily applicable and computationally affordable approach. The developed method fulfills this requirement.

The power-to-heat concept manifested naturally from the available component mix of PV panels, thermal storage, and heat pump. In this case, it was demonstrated as the capability to convert excess solar electricity production to heat with the heat pump and store it in the thermal storage for later consumption. This concept could turn out as an essential function in future carbon-free energy systems. Studying this approach more specifically, however, is outside the scope of this study and requires further research.

The retrofit dimensioning results of the case campus building are significant and puzzling. Due to high emissions from manufacturing of photovoltaic panels and lithiumion batteries in addition to low $\mathrm{CO}_{2}$ factors of imported energy, no life cycle emission reductions appear to be gained from installing additional PV panels or batteries for the 25 -year lifetime in this case. This result significantly diverges from the presumption that local renewable energy production and storage provide environmental life cycle emission benefits. The conclusion is not directly generalizable, however, as it depends on the specific building and its equipment, local $\mathrm{CO}_{2}$ emission factors, and projections that electricity and district heat imported from the energy networks will be carbon neutral after 25 years. Future research needs to cover more buildings in different locations to study differences between geographical areas.

The sensitivity and feasibility analyses of the case results indicate that correct imported energy and component life cycle emission values are crucial for reliable environmental optimization. Sourcing of correct life cycle emission data for components such as lithiumion batteries requires knowledge of the manufacturing location and detailed specifications. Furthermore, emission factors of imported grid energy are rapidly decreasing, as electricity and DH networks in Finland are converting to carbon-neutral production, and the reported values do not always represent the full life cycle. This complicates the sourcing of reliable input values for environmental optimization and causes the results to expire rapidly.

The presented optimization approach considers only a single building. For cost optimization, this seems feasible, as the incentives are clear for the property owner in the form of cost savings. However, emission minimization has currently no tangible incentive for the property owner and may thus remain unimplemented. Furthermore, the environmental optimization result with no installed PV panels seems to conflict with the fact that small-scale distributed renewable energy generation including PV is generally considered a requirement for carbon-neutral electricity networks. Applicable results would probably require optimization on several system levels and coordination between them. In the future, frameworks such as emissions trade could be further extended to translate these considerations into the monetary domain.

Based on the previous points, it would seem feasible that especially in future renewable energy systems, reported specific energy emissions included life cycle emissions from system manufacture, deployment, operation, decommissioning, and other considerations, instead of only direct emissions from combustion. The current methodological discrepancies in emission factors complicate emission optimization and cause uncertainty in the 
results. Naturally, the situation might change with future regulations or incentives, but the field still needs further research. Currently, for a building owner, single-objective cost optimization could be the most sensible approach due to its clear incentives and robustness.

Author Contributions: Conceptualization, V.E., A.G. and A.W.; data curation, V.E. and A.W.; investigation, V.E., A.G. and A.W.; methodology, V.E. and A.G.; project administration, A.G.; software, V.E.; validation, V.E. and A.G.; writing — original draft, V.E. and A.W.; writing—review and editing, V.E., A.G. and A.W. All authors have read and agreed to the published version of the manuscript.

Funding: This study received funding from the European Regional Development Fund (ERDF) under project A75174.

Institutional Review Board Statement: Not applicable.

Informed Consent Statement: Not applicable.

Data Availability Statement: The data presented in this study are available on request from the corresponding author.

Conflicts of Interest: The authors declare no conflict of interest. The funders had no role in the design of the study; in the collection, analyses, or interpretation of data; in the writing of the manuscript, or in the decision to publish the results.

\section{Appendix A}

Appendix A contains floor plans of the modeled case building. Variable $z$ represents the vertical coordinate.

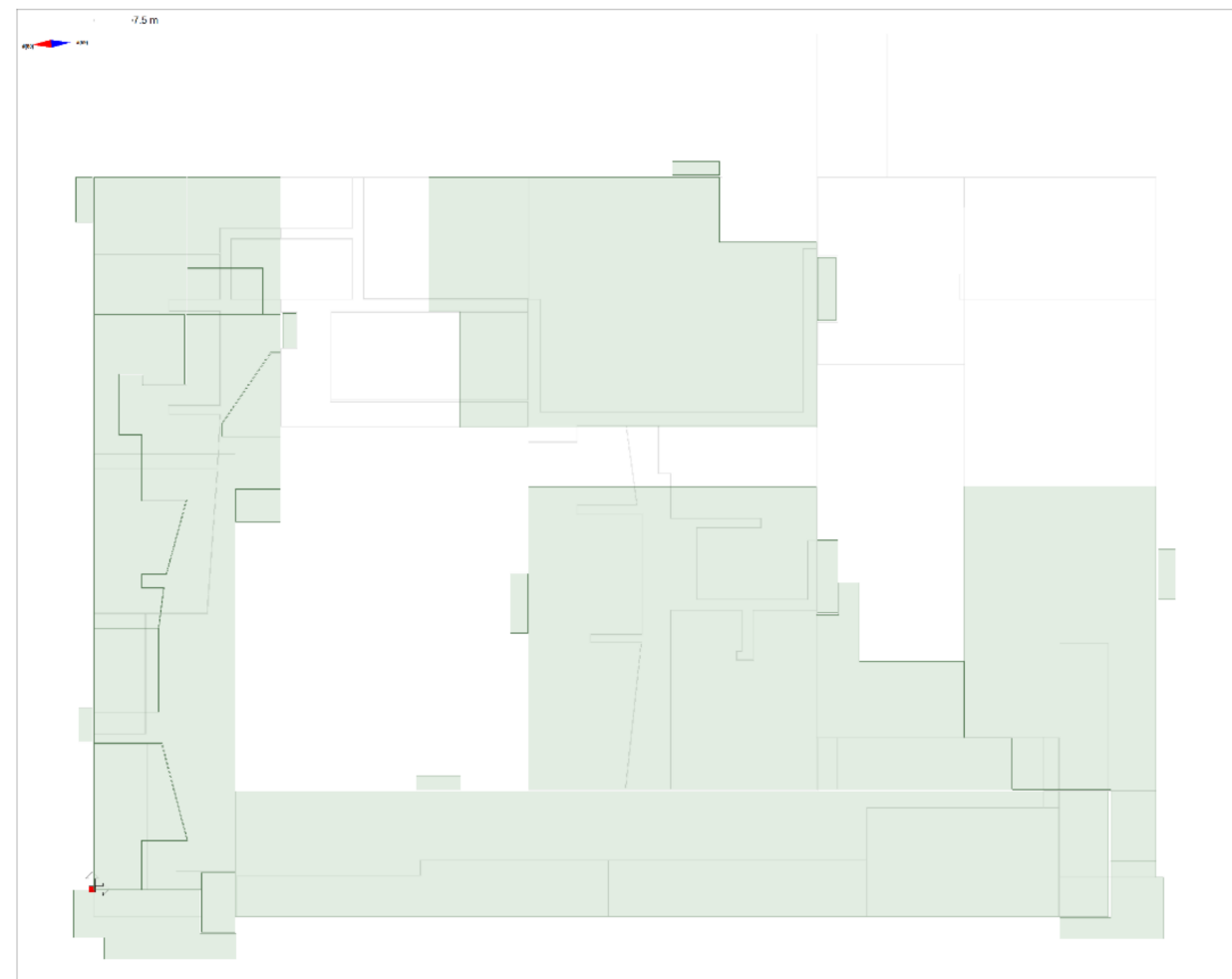

Figure A1. First floor $(z=0.0 \mathrm{~m})$. 


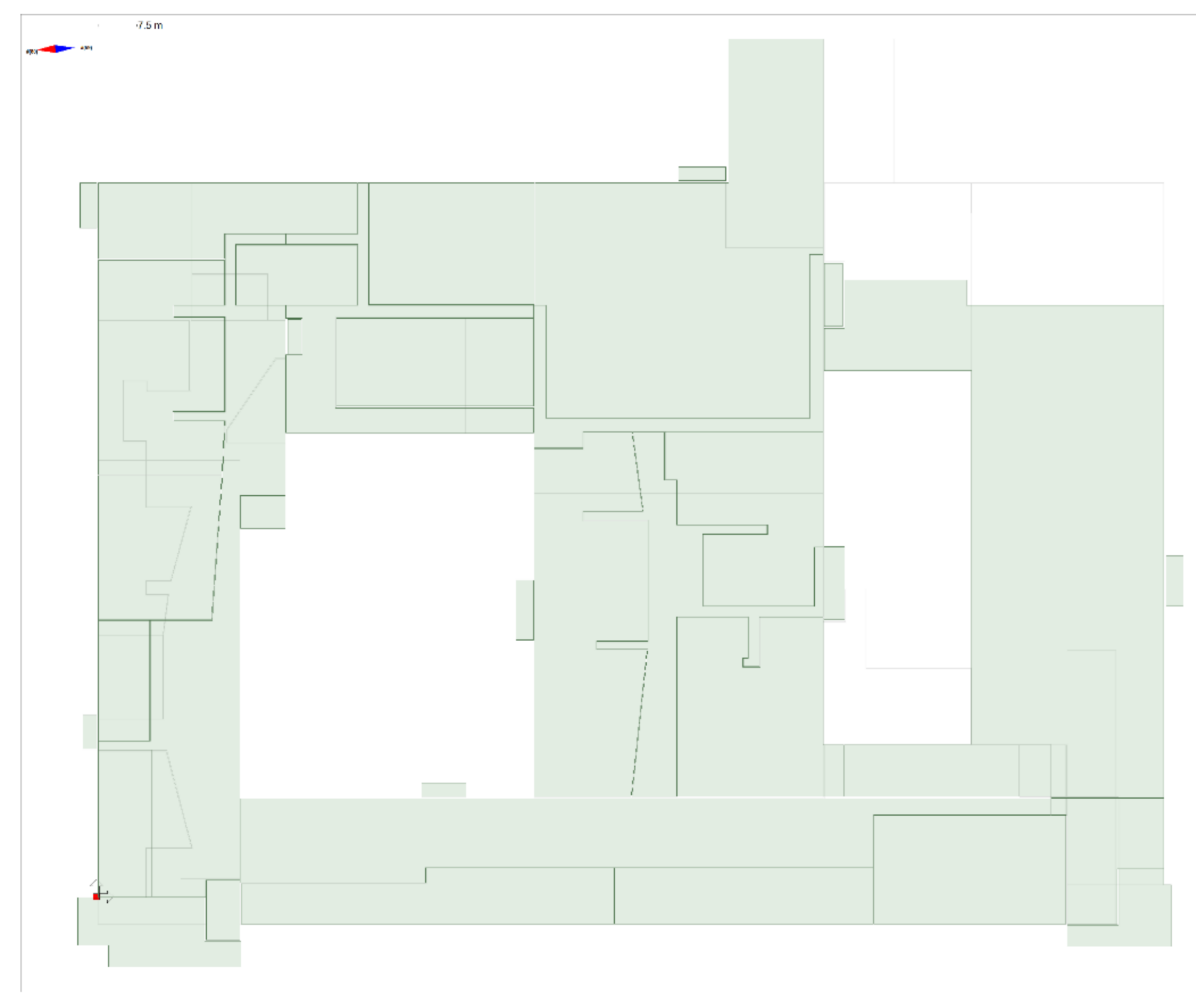

Figure A2. Second floor $(z=4.5 \mathrm{~m})$.

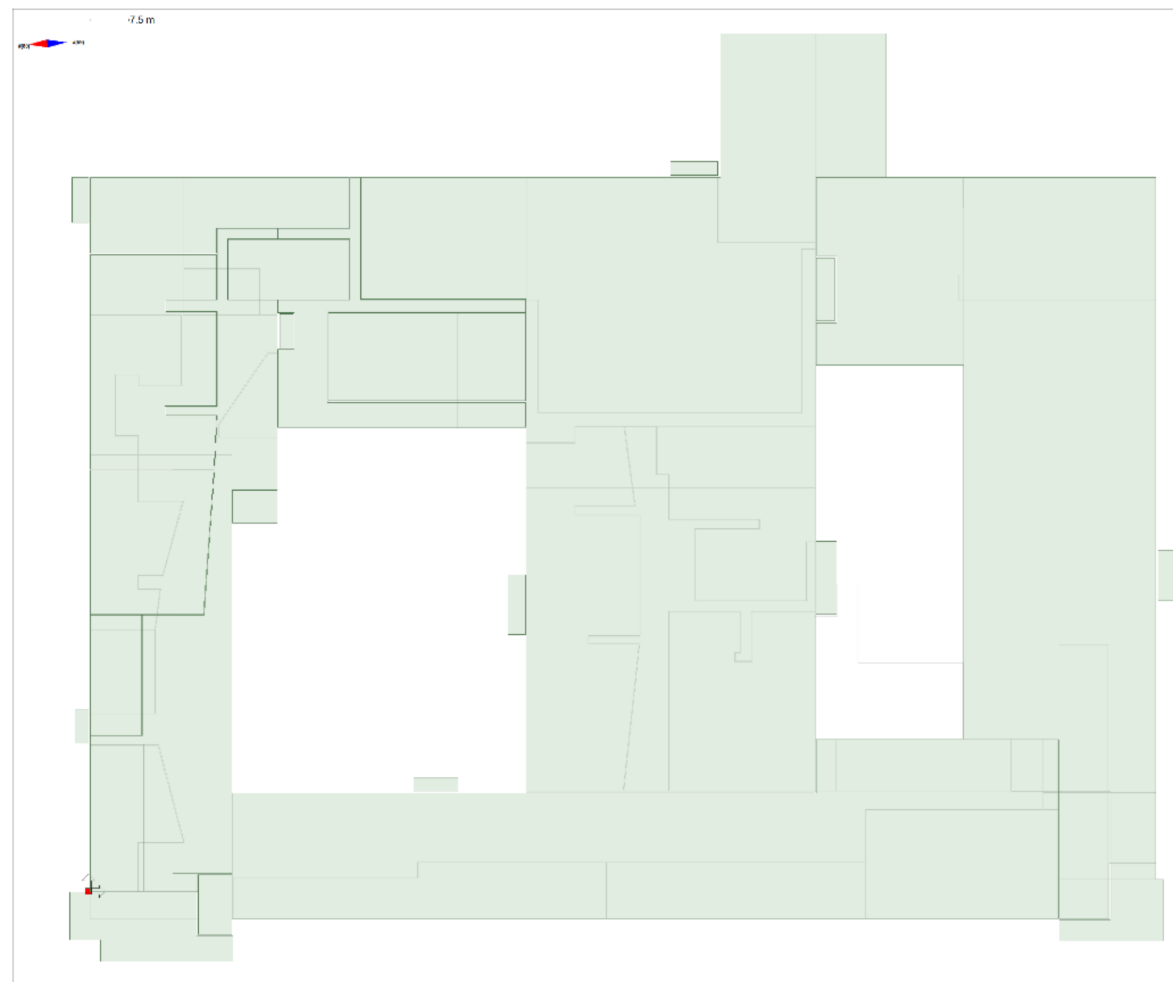

Figure A3. Third floor $(z=9.0 \mathrm{~m})$. 


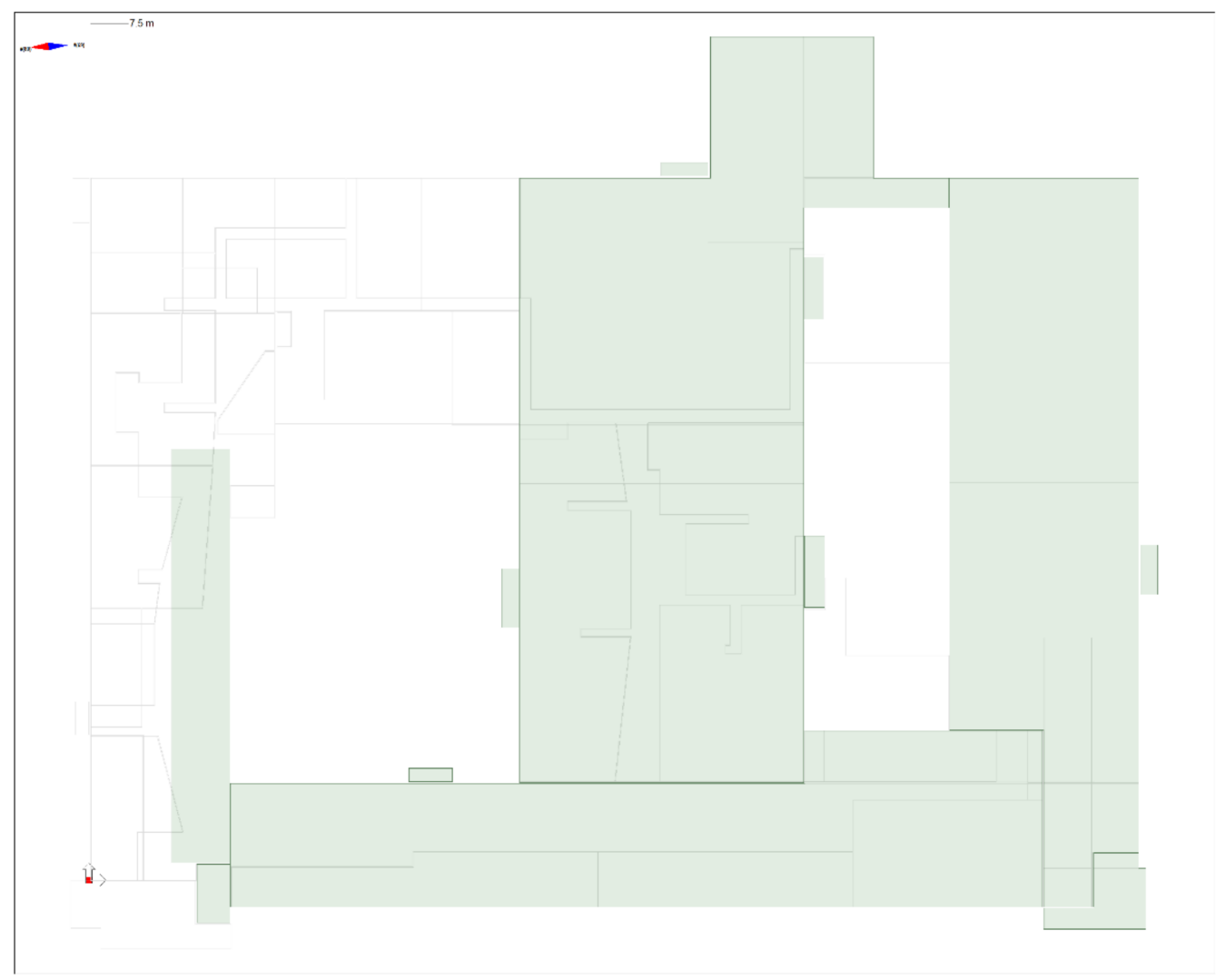

Figure A4. Fourth floor $(z=13.5 \mathrm{~m})$.

\section{References}

1. IEA. Buildings-Topics. Available online: https:/ / www.iea.org/topics/buildings (accessed on 16 June 2021).

2. European Commission. Energy Performance of Buildings Directive. Available online: https://ec.europa.eu/energy/topics/ energy-efficiency/energy-efficient-buildings/energy-performance-buildings-directive_en (accessed on 16 June 2021).

3. Motiva. Aurinkosähköjärjestelmän Mitoitus (Solar Electricity System Dimensioning). Available online: https://www.motiva.fi/ ratkaisut/uusiutuva_energia/aurinkosahko/hankinta_ja_asennus/aurinkosahkojarjestelman_mitoitus (accessed on 16 June 2021).

4. EQUA Simulation AB. IDA ICE-Simulation Software. Available online: https:/ / www.equa.se/en/ida-ice (accessed on 18 June 2021).

5. National Renewable Energy Laboratory; U.S. Department of Energy. EnergyPlus. Available online: https://energyplus.net/ (accessed on 30 June 2021).

6. Thermal Energy System Specialists, LLC. TRNSYS: Transient System Simulation Tool. Available online: http://www.trnsys.com/ (accessed on 30 June 2021).

7. Becchio, C.; Ferrando, D.G.; Fregonara, E.; Milani, N.; Quercia, C.; Serra, V. The Cost-Optimal Methodology for the Energy Retrofit of an Ex-Industrial Building Located in Northern Italy. Energy Build. 2016, 127, 590-602. [CrossRef]

8. Wu, R.; Mavromatidis, G.; Orehounig, K.; Carmeliet, J. Multiobjective Optimisation of Energy Systems and Building Envelope Retrofit in a Residential Community. Appl. Energy 2017, 190, 634-649. [CrossRef]

9. Ascione, F.; Bianco, N.; De Stasio, C.; Mauro, G.M.; Vanoli, G.P. A New Methodology for Cost-Optimal Analysis by Means of the Multi-Objective Optimization of Building Energy Performance. Energy Build. 2015, 88, 78-90. [CrossRef]

10. Bingham, R.D.; Agelin-Chaab, M.; Rosen, M.A. Whole Building Optimization of a Residential Home with PV and Battery Storage in The Bahamas. Renew. Energy 2019, 132, 1088-1103. [CrossRef]

11. Delgarm, N.; Sajadi, B.; Kowsary, F.; Delgarm, S. Multi-Objective Optimization of the Building Energy Performance: A SimulationBased Approach by Means of Particle Swarm Optimization (PSO). Appl. Energy 2016, 170, 293-303. [CrossRef]

12. Hamdy, M.; Mauro, G.M. Multi-Objective Optimization of Building Energy Design to Reconcile Collective and Private Perspectives: $\mathrm{CO}_{2}$-Eq vs. Discounted Payback Time. Energies 2017, 10, 1016. [CrossRef]

13. Milan, C.; Bojesen, C.; Nielsen, M.P. A Cost Optimization Model for $100 \%$ Renewable Residential Energy Supply Systems. Energy 2012, 48, 118-127. [CrossRef]

14. Privitera, G.; Day, A.R.; Dhesi, G.; Long, D. Optimising the Installation Costs of Renewable Energy Technologies in Buildings: A Linear Programming Approach. Energy Build. 2011, 43, 838-843. [CrossRef]

15. Di Pilla, L.; Desogus, G.; Mura, S.; Ricciu, R.; Di Francesco, M. Optimizing the Distribution of Italian Building Energy Retrofit Incentives with Linear Programming. Energy Build. 2016, 112, 21-27. [CrossRef] 
16. Lindberg, K.B.; Doorman, G.; Fischer, D.; Korpås, M.; Ånestad, A.; Sartori, I. Methodology for Optimal Energy System Design of Zero Energy Buildings Using Mixed-Integer Linear Programming. Energy Build. 2016, 127, 194-205. [CrossRef]

17. Omu, A.; Choudhary, R.; Boies, A. Distributed Energy Resource System Optimisation Using Mixed Integer Linear Programming. Energy Policy 2013, 61, 249-266. [CrossRef]

18. Ren, F.; Wei, Z.; Zhai, X. Multi-Objective Optimization and Evaluation of Hybrid CCHP Systems for Different Building Types. Energy 2021, 215, 119096. [CrossRef]

19. Xu, Y.; Zhang, G.; Yan, C.; Wang, G.; Jiang, Y.; Zhao, K. A Two-Stage Multi-Objective Optimization Method for Envelope and Energy Generation Systems of Primary and Secondary School Teaching Buildings in China. Build. Environ. 2021, $204,108142$. [CrossRef]

20. Attia, S.; Hamdy, M.; O’Brien, W.; Carlucci, S. Assessing Gaps and Needs for Integrating Building Performance Optimization Tools in Net Zero Energy Buildings Design. Energy Build. 2013, 60, 110-124. [CrossRef]

21. Nguyen, A.-T.; Reiter, S.; Rigo, P. A Review on Simulation-Based Optimization Methods Applied to Building Performance Analysis. Appl. Energy 2014, 113, 1043-1058. [CrossRef]

22. Li, L. Integrating Climate Change Impact in New Building Design Process: A Review of Building Life Cycle Carbon Emission Assessment Methodologies. Clean. Eng. Technol. 2021, 5, 100286. [CrossRef]

23. Ibañez Iralde, N.S.; Pascual, J.; Salom, J. Energy Retrofit of Residential Building Clusters. A Literature Review of Crossover Recommended Measures, Policies Instruments and Allocated Funds in Spain. Energy Build. 2021, 252, 111409. [CrossRef]

24. Galatioto, A.; Ciulla, G.; Ricciu, R. An Overview of Energy Retrofit Actions Feasibility on Italian Historical Buildings. Energy 2017, 137, 991-1000. [CrossRef]

25. Gagliano, A.; Nocera, F.; Tina, G. Performances and Economic Analysis of Small Photovoltaic-Electricity Energy Storage System for Residential Applications. Energy Environ. 2020, 31, 155-175. [CrossRef]

26. He, Q.; Hossain, M.U.; Ng, S.T.; Augenbroe, G. Identifying Practical Sustainable Retrofit Measures for Existing High-Rise Residential Buildings in Various Climate Zones through an Integrated Energy-Cost Model. Renew. Sustain. Energy Rev. 2021, 151, 111578. [CrossRef]

27. Nocera, F.; Giuffrida, S.; Trovato, M.R.; Gagliano, A. Energy and New Economic Approach for Nearly Zero Energy Hotels. Entropy 2019, 21, 639. [CrossRef] [PubMed]

28. Pirmohamadi, A.; Dastjerdi, S.M.; Ziapour, B.M.; Ahmadi, P.; Rosen, M.A. Integrated Solar Thermal Systems in Smart Optimized Zero Energy Buildings: Energy, Environment and Economic Assessments. Sustain. Energy Technol. Assess. 2021, 48, 101580. [CrossRef]

29. Pfenninger, S.; Pickering, B. Calliope: A Multi-Scale Energy Systems Modelling Framework. J. Open Source Softw. 2018, 3, 825. [CrossRef]

30. Child, M.; Breyer, C. Vision and Initial Feasibility Analysis of a Recarbonised Finnish Energy System for 2050. Renew. Sustain. Energy Rev. 2016, 66, 517-536. [CrossRef]

31. Litjens, G.B.M.A.; Worrell, E.; Van Sark, W.G.J.H.M. Lowering Greenhouse Gas Emissions in the Built Environment by Combining Ground Source Heat Pumps, Photovoltaics and Battery Storage. Energy Build. 2018, 180, 51-71. [CrossRef]

32. Baeten, B.; Rogiers, F.; Helsen, L. Reduction of Heat Pump Induced Peak Electricity Use and Required Generation Capacity through Thermal Energy Storage and Demand Response. Appl. Energy 2017, 195, 184-195. [CrossRef]

33. Huang, Y.J.; Su, F.; Seo, D.; Krarti, M. Development of 3012 IWEC2 Weather Files for International Locations (RP-1477). ASHRAE Trans. 2014, 120, 340-355.

34. Motiva. Kulutuksen Normitus (Standardisation of Consumption). Available online: https://www.motiva.fi/julkinen_sektori/ kiinteiston_energiankaytto/kulutuksen_normitus (accessed on 18 June 2021).

35. Finnish Meteorological Institute. Heating Degree Days. Available online: https://en.ilmatieteenlaitos.fi/heating-degree-days (accessed on 19 August 2021).

36. Pfenninger, S.; Pickering, B.; Tröndle, T.; Garchery, M.; Hawker, G.; Lombardi, F.; Hilbers, A. Calliope 0.6.7 documentation. Available online: https:/ / calliope.readthedocs.io/en/v0.6.7/ (accessed on 27 August 2021).

37. Eslami-nejad, P.; Bernier, M. Freezing of Geothermal Borehole Surroundings: A Numerical and Experimental Assessment with Applications. Appl. Energy 2012, 98, 333-345. [CrossRef]

38. GTK (Geological Survey of Finland). Maankamara (Earth Crust Map). Available online: https://gtkdata.gtk.fi/Maankamara/ (accessed on 17 June 2021).

39. Philipps, S.; Warmuth, W. Photovoltaics Report. Fraunhofer Institute for Solar Energy Systems. Available online: https://www.ise. fraunhofer.de/content/dam/ise/de/documents/publications/studies/Photovoltaics-Report.pdf (accessed on 5 August 2021).

40. Yıldız, G.; Çalış, B.; Gürel, A.E.; Ceylan, İ. Investigation of Life Cycle $\mathrm{CO}_{2}$ Emissions of the Polycrystalline and Cadmium Telluride PV Panels. Environ. Nanotechnol. Monit. Manag. 2020, 14, 100343. [CrossRef]

41. Liu, F.; Van den Bergh, J.C.J.M. Differences in $\mathrm{CO}_{2}$ Emissions of Solar PV Production among Technologies and Regions: Application to China, EU and USA. Energy Policy 2020, 138, 111234. [CrossRef]

42. Hauer, A.; Simbolotti, G.; Tosato, G.; Gielen, D. Thermal Energy Storage; IEA-ETSAP: Paris, France; IRENA: Abu Dhabi, United Arab Emirates, 2013.

43. IRENA. Electricity Storage and Renewables: Costs and Markets to 2030; International Renewable Energy Agency: Abu Dhabi, United Arab Emirates, 2017; ISBN 978-92-9260-038-9. 
44. Thaker, S.; Oni, A.O.; Gemechu, E.; Kumar, A. Evaluating Energy and Greenhouse Gas Emission Footprints of Thermal Energy Storage Systems for Concentrated Solar Power Applications. J. Energy Storage 2019, 26, 100992. [CrossRef]

45. Philippot, M.; Alvarez, G.; Ayerbe, E.; Van Mierlo, J.; Messagie, M. Eco-Efficiency of a Lithium-Ion Battery for Electric Vehicles: Influence of Manufacturing Country and Commodity Prices on GHG Emissions and Costs. Batteries 2019, 5, 23. [CrossRef]

46. Pucker-Singer, J.; Aichberger, C.; Zupančič, J.; Neumann, C.; Bird, D.N.; Jungmeier, G.; Gubina, A.; Tuerk, A. Greenhouse Gas Emissions of Stationary Battery Installations in Two Renewable Energy Projects. Sustainability 2021, 13, 6330. [CrossRef]

47. Fingrid. Sähköjärjestelmän tila- $\mathrm{CO}_{2}$ (Electricity System State- $\mathrm{CO}_{2}$ ). Available online: https://www.fingrid.fi/sahkomarkkinat/ sahkojarjestelman-tila/co2/ (accessed on 21 June 2021).

48. Lahti Energia. Vastuullisuusraportti (Sustainability Report). Available online: https://www.lahtienergia.fi/vastuullisuusraportti/ (accessed on 21 June 2021).

49. Statistics Finland. Energy Prices. ISSN=1799-800X. 1st Quarter 2021, Appendix Figure 5. Price of Electricity by Type of Consumer. Available online: https://www.stat.fi/til/ehi/2021/01/ehi_2021_01_2021-06-10_kuv_005_en.html (accessed on 5 August 2021).

50. LE-Sähköverkko Oy. Verkkopalveluhinnasto 1.8.2019 alkaen (Electricity Network Service Price List as of 2019-08-01). Available online: https:/ / www.lahtienergia.fi/wp-content/uploads/2021/06/verkkopalveluhinnasto_01082019.pdf (accessed on 5 August 2021).

51. Lahti Energia. Lämpömaksuhinnasto (Heat Price List). Available online: https://www.lahtienergia.fi/wp-content/uploads/2021 /06/Lampomaksuhinnasto-01122020-ilman-palveluhinnastoa.pdf (accessed on 5 August 2021).

52. Statistics Finland. Energy Prices. ISSN=1799-800X. 1st Quarter 2021, Appendix Figure 6. Average Monthly Spot Prices at the Nord Pool Spot Power Exchange. Available online: https://www.stat.fi/til/ehi/2021/01/ehi_2021_01_2021-06-10_kuv_006_en.html (accessed on 5 August 2021). 